\title{
Distance learning in Italian primary and middle school children during the COVID- 19 pandemic: a national survey
}

Francesca Scarpellini* (D), Giulia Segre, Massimo Cartabia, Michele Zanetti, Rita Campi, Antonio Clavenna and Maurizio Bonati

\begin{abstract}
Background: School closure created difficulties for parents, who were asked to care for their children and help them with schooling, while working at home. We aimed to explore the experiences in organising school for children at home and its implications on children's psychological well-being and educational progress during the quarantine for the COVID-19 pandemic.

Methods: A nationwide online survey of mothers of primary and middle school students was conducted during the COVID-19 pandemic. Demographic data and information on distance learning organisation and children's attitudes and behavioural changes were collected.

Results: 2149 mothers completed the survey, with a final sample of 1601 subjects. Large differences between primary and middle school emerged: lessons were less organised and routines were more instable for the youngest, who could not pay attention for more than $20 \mathrm{~min}(28.3 \%)$ and needed breaks every $10 \mathrm{~min}(21.6 \%)$, with lower quality of learning (40.6\%), increased restlessness (69.1\%), and aggressiveness (33.3\%). A large use of screens was reported, with an abuse in screen time in $2 \%$. Two thirds of mothers did not approve of distance learning (72.2\%) because of their role in replacing teachers (77.8\%), the effort required $(66 \%)$, and the great commitment required (78.3\%).

Conclusions: Distance learning increased educational deprivation and social inequalities, especially for the youngest children, who lost almost one year of school. The situation was even worse for children with disabilities, who were neglected by the institutions. This period should be considered as an opportunity to correct the weaknesses of our school system.
\end{abstract}

Keywords: Distance education, surveys and questionnaires, COVID-19, child psychology, quarantine, social isolation, children's mental health, home learning

\footnotetext{
* Correspondence: francesca.scarpellini@marionegri.it

Laboratory for Mother and Child Health, Department of Public Health,

Istituto di Ricerche Farmacologiche Mario Negri IRCCS, Via Mario Negri 2,

20156 Milan, Italy
}

(c) The Author(s). 2021 Open Access This article is licensed under a Creative Commons Attribution 4.0 International License, which permits use, sharing, adaptation, distribution and reproduction in any medium or format, as long as you give appropriate credit to the original author(s) and the source, provide a link to the Creative Commons licence, and indicate if changes were made. The images or other third party material in this article are included in the article's Creative Commons licence, unless indicated otherwise in a credit line to the material. If material is not included in the article's Creative Commons licence and your intended use is not permitted by statutory regulation or exceeds the permitted use, you will need to obtain permission directly from the copyright holder. To view a copy of this licence, visit http://creativecommons.org/licenses/by/4.0/ The Creative Commons Public Domain Dedication waiver (http://creativecommons.org/publicdomain/zero/1.0/) applies to the data made available in this article, unless otherwise stated in a credit line to the data. 


\section{Background}

In response to the recent coronavirus disease 2019 (COVID-19) emergency, the Italian government closed all schools on February 23rd in order to prevent the spread of the virus in its territory. In Italy, about 8.5 million students remained confined at home [1], as in other 185 countries of the world. This affected 1.56 billion children and young people: about $89.6 \%$ of the global student population [2]. Education, however, was not interrupted and continued online. In order to guarantee educational rights, great efforts were carried out by the Italian Minister of Instruction and by the teachers to plan distance learning and ensure the continuity of classrooms through web platforms, videoconference tools, and social devices. Online schooling preserved the continuity of the academic year, although this solution created some problems for families' well-being. Evidence of the effect of distance learning on preventing a virus' diffusion is lacking from previous pandemics [3], whereas a few evaluations were carried out for the COVID-19 pandemic [4-6]. The severe consequences of school closures were not justified by the clinical picture of Italian children [7].

In Italy $42 \%$ of minors live in a condition of overpopulation in their own house and 7\% of children and adolescents are victims of great housing distress [8]. In these houses young students have difficulties finding a quiet place in which to study, follow lessons, and do homework. In Europe, children who live in families with poor economic conditions were unable to take part in distance learning because of the absence of an internet connection or technological devices such as computers, and because of a lack of support in accessing the lessons [9, 10]. This meant that a significant group of children may have been excluded not only from learning, but also from any form of socialisation with peers and with the surrounding world. The educational inequalities and deprivation were even more serious for those who suffered from a chronic pathology, whether physical or neurocognitive, that required special educational needs [1114]. The home confinement and the absence of social contacts represented risk factors for the development of psychological distress and other negative consequences $[15,16]$. Research has shown that prolonged stress, boredom, and social isolation may lead to a higher number of mental health conditions in children, such as restlessness, aggressiveness, anxiety, and depression [17-19]. The interruption of school leads youth to spend a lot of time in front of screens and to reduce social interactions and time dedicated to sports, with consequences on sleeping rhythms and eating habits [20]. It has been estimated that 12 weeks of school interruption drops test scores significantly [21]. The protracted closure of schools represents a serious risk for the psychological well-being of children and their entire households. Parents and caregivers attempted to work remotely while caring for children. Because of parents' home office situations and lack of multiple computers, several family members, including children who had to study, needed to use the devices contemporaneously [22]. An Italian survey conducted in April involved parents of 2-14 year old children and revealed that difficulties in dealing with quarantine had consequences on the entire family's level of stress. Parents who reported having more problems taking care of children's learning, finding space and time for themselves, their partners, their children, or for the activities they used to do before the lockdown, were more stressed. This, in turn, led to increased psychological symptoms in children [23]. Another online survey, conducted on 3.013 adults from 24th April to 4th May in the USA, reported that more than 7 in 10 parents felt that managing distance/online learning for their children was a significant source of stress (71\%) [24]. In this period numerous articles were published regarding children's and adult's psychological distress due to COVID-19, but little is known about problems related to school closure $[22,25,26]$. Schools are a vital source of care for young children, and that without in-person instruction; mothers have been sidelined from the labor force [27]. Similarly, the findings on another study highlighted gender differences in the contribution to childcare but also in pandemic-related altered working conditions, with mothers being more likely to work in a system-relevant occupation, to work onsite and to change their working hours compared to fathers [28]. In order to analyze the impact of school closure and other containment restrictions on various outcomes related to children and family well-being, different surveys or interviews were addressed to mothers [29, 30]. For this reason, we involved mothers of primary and middle school students in order to collect information on their experiences with home-school organisation and its difficulties, and their opinions concerning distance learning. The aim of this study was to explore the current educational situation in Italy during the COVID-19 pandemic and the impact of school closure on the educational progress and behavioural impairment of children.

\section{Methods}

\section{Participants and procedures}

This was a cross-sectional, observational study carried out in Italy. A dedicated website was created for the purpose of this study. An online, structured questionnaire was developed by using Wordpress, a free open-source content management system (CMS), integrated with SurveyJS (survey library and survey creator), a library to facilitate survey creation and management. Answers were restricted to close-ended fixed choices; the survey 
script was available for all devices. The survey began online on May $8^{\text {th }}$, was available for one week, until May $15^{\text {th }}$, and targeted mothers of children of primary and middle school (children aged 6-15 years old). In that period, positive cases in Italy were decreasing and the nation was living a particular phase of progressive reopening. Italian families were emerging from quarantine and it was progressively possible to meet one's own relatives again. Many activities were resuming and parents were being asked to return to work, while schools were still closed and the educational situation still hadn't been defined. The survey was addressed only to mothers, not minors, and was motivated. Moreover, according to previous studies, participation of women in research is usually greater than that of men [27]. No validated questionnaires related to the specific problem of school closure during a pandemic emergency were found in the literature, so we created the questions ad hoc, starting from the requests of parents published in journals and magazines in that time period, as well as from mothers' messages received via e-mail by the Laboratory for Mother and Child Health of the Mario Negri Research Institute (See Additional File 1). The authors assert that all procedures contributing to this work comply with the ethical standards of the relevant national and institutional guidelines on care and clinical research. This study has been conducted in accordance with the Helsinky Declaration. The study was approved by the ethics committee of the San Paolo hospital (2020/ST/106) of Milan, Italy. Participation was voluntary and free; no incentives were offered to complete it. Informed consent to participate in the study was obtained only from parents before accepting to take the survey. Minors were not involved in the study. Once the link of the survey was clicked on, the participants were automatically directed to information on the study and to the informed consent.

All the items of the STROBE checklist for observational studies have been met in the present report.

\section{Measures}

The questionnaire was created in Italian and, to submit it to as many people as possible, a snowball sampling technique was used. The link to the questionnaire was sent by e-mail, WhatsApp, and other social media to the investigators' relatives. To encourage involvement, the invitation was sent to different mailing lists of people who were in contact with the institute. Once the link was clicked on, the participants were automatically directed to information on the study and to the informed consent. After accepting to take the survey, a set of socio-demographic questions appeared, which included age, gender, occupation, education, and area of residence, followed by other questions.
The questionnaire consisted of four sections investigating:

- Socio-demographic variables: about the mother (nationality, age, residential area, educational level, profession, number of room in the house, support from others, such as relatives, friends, or nannies, before the quarantine) and about the children (age, gender, brothers or sisters, school grade and type of school, academic achievement, chronic disorders, and support teachers).

- Distance learning organisation (with or without special needs): types of tools (e.g. PC, tablet, books) adopted and frequency of use, changes in school routine, whether teachers were reachable, effort required of the child, and learning assessment.

\section{- Children's attitude and behavioural changes:} level of attention during e-learning, frequency of breaks, time spent on screens, level of commitment and autonomy in keeping up with the school programme, behavioural changes (anxiety, restlessness, aggressiveness, and sleeping or mood disorders). Each symptom was rated as mild, moderate or severe.

- Mother's difficulties and opinion on distance learning: difficulties in managing work tasks and home schooling, effort required and level of commitment in supporting children, distance learning implications, and future perspectives for the upcoming school re-opening.

\section{Statistical analysis}

Data are reported as number and percentage of responders to compare the characteristics of primary school and middle school students. Data analysis was performed using frequency distributions for categorical variables, reported as number of responders, and summarized using percentages. Associations were tested using chi-square or Fisher's exact test where applicable. Continuous variables were summarized using median and interquartile range and statistically significant differences were evaluated using two sample Wilcoxon's test. Where data were missing, in analyses of prevalenceevaluated characteristics, we used pairwise deletion, so that all variable data were used; and in analyses of odd ratios (OR), we used listwise deletion, so that data from the same participants were used in bivariate and multivariate models, enabling comparison. Sensitivity analysis was performed by running two separate models, adding confounders with missing values. Statistical significance was evaluated using 95\% confidence interval and a twotailed $p$-value of $<0.05$. All the statistical analyses were performed using SAS software, version 9.4 (SAS, Institute Inc., Cary, NC, USA). 


\section{Results}

Socio-demographic information on mothers and children In total, 1,601 responders completed the online survey. Of these, $70.2 \%$ were from northern Italy, and, in particular, 50.7\% were from the Lombardy Region (the most represented and representative in the survey, and the one that suffered the most from the virus in Italy and in the world at the time of the survey). The mothers were $39-49$ years old, had a tertiary level of education (46.6\%), and were mainly workers (66\%) as employees (64.7\%), and were making use of the smart working option (i.e. working from home, $62.5 \%$ ). The majority of mothers had children in primary school $(71.7 \%)$ and reported greater difficulties in providing support for their children's educational learning than mothers of older students $(\mathrm{OR}=3.16, \mathrm{CI} 2.23-4.47)$. Children were 7-13 years old, 1148 from primary school, and 453 from middle school. Those who attended primary school were more frequently an only child (OR $=1.70$, CI 1.34-2.16). The majority of students attended public school, but private schools had a larger proportion of primary school students $(\mathrm{OR}=1.96$, CI 1.27-3.02). School performance before quarantine was, for the majority of the students, good or better $(88.7 \%)$, with higher results for the primary school students and lower performance for middle school students (Table 1).

\section{Distance learning organisation \\ Tools}

The most commonly used instruments were computer, PC, smartphone/tablet, and books, the latter especially in primary school $(\mathrm{OR}=1.46, \mathrm{CI} 1.16-1.83)$. Most $(80.7 \%)$ respondents had no difficulties with the use of technology, but $1.5 \%$ was not able to use it because the instruments were not available. The frequency of PC use was lower in primary school students $(\mathrm{OR}=3.48, \mathrm{CI}$ 2.06-5.90). Both groups used web-platform tools (59.5\%) such as Edmodo or Google Suites for Education, messaging tools (42.7\%), WhatsApp or FaceTime, and the videoconference tools (22.9\%) Zoom or Skype. The electronic register software was less used by primary school teachers $(\mathrm{OR}=0.45, \mathrm{CI} 0.35-0.57)$, which preferred to use YouTube $(\mathrm{OR}=1.44, \mathrm{CI} 1.14-1.83)$. However, $47.7 \%$ of respondents reported that none of the mentioned tools was used by the school. The frequency of web tools use was lower for primary school children $(\mathrm{OR}=3.58$, CI 2.45-5.23). Video-lessons (recorded or in streaming) were conducted mainly by middle school teachers $(\mathrm{OR}=$ 0.39 , CI 0.27-0.56), as well as studying with books (OR = 0.52 , CI $0.41-0.65)$. For both groups the teaching modalities were assigning homework (91.4\%), watching films and documentaries (62.9\%), and sending students school materials and documents (59.4\%) such as slides and links.

\section{Learning organisation}

About one fourth (26.8\%) of respondents considered distance learning disorganised and characterised by a different routine compared to presence in school, especially for primary school students. More specifically, primary school students were faced with more instable routines $(\mathrm{OR}=1.50, \mathrm{CI} 1.24-2.01)$ and less organisation $(\mathrm{OR}=$ 1.42, CI 1.09-1.85). Great effort, however, was required for studying and doing homework for both groups (81.2\%).

According to $31.1 \%$ of respondents, teachers could not be contacted, although primary school teachers were more easily available than middle school teachers $(\mathrm{OR}=$ $0.55, \mathrm{CI}=0.44-0.70)$.

\section{Learning assessment}

Assessment was carried out in $90.5 \%$ of students and mainly consisted of teachers' homework revision (74.3\%) without attribution of grades $(43.8 \%)$, in particular in primary school. In middle school, tests and oral exams were mostly planned (77.7\%) and grades varied from previous school performance, with lower grades almost twice as likely in primary school students $(\mathrm{OR}=0.49, \mathrm{CI}$ $0.30-0.78)$. Concerning primary schools, $11.5 \%$ of students were not assessed and more than half did not receive any grades (Table 2).

\section{Children's attitude and behavioural changes}

Children's attitude towards distance learning differed between the youngest and oldest. Primary school students could not pay attention for more than 20 minutes $(\mathrm{OR}=$ 2.39, CI 1.75-3.25), needed breaks every 10 minutes (OR $=2.25$, CI 1.53-3.30), and presented more restlessness during video lessons $(\mathrm{OR}=1.37, \mathrm{CI} 1.10-1.72)$. Results also revealed a large use of screens (minimum 2 hours of video lessons per day for more than half of students). This was especially true for middle school students, who spent several hours in front of a screen, considering both distance learning and screen time other than distance learning compared to primary school students. In $2 \%$ of the students there was an abuse of media use, with $8-12$ hours of screen time. Primary school students spent less time on internet activities such as videogames $(\mathrm{OR}=$ 0.53 , CI 0.42-0.66) and social networks (OR $=0.16, \mathrm{CI}$ $0.12-0.21)$ than middle school students.

A majority (60.2\%) of mothers observed behavioural changes in their children, in particular in the youngest $(\mathrm{OR}=1.39$, CI 1.11-1.73). The most frequently observed symptoms were restlessness (69.1\%) and aggressiveness $(33.3 \%)$ in the youngest, and anxiety $(34.2 \%)$ in the oldest. No differences emerged between subjects concerning sleeping rhythm and mood lability. The level of restlessness and aggressiveness was particularly severe for primary school children $(\mathrm{OR}=1.72$, CI $1.26-2.44 ; \mathrm{OR}=$ 
Table 1 Socio-demographics mothers and children variables by School

\begin{tabular}{|c|c|c|c|c|c|c|}
\hline & Primary school & Middle school & Total & OR & $\mathrm{Cl} 95 \%$ & p-value \\
\hline \multicolumn{7}{|l|}{ Mothers } \\
\hline Age & $42,5(39,0-46,0)$ & $46,0(43,0-49,0)$ & $44,0(39-49)$ & & & $<0.0001$ \\
\hline \multicolumn{7}{|l|}{ Region } \\
\hline North & $775(68.1)$ & $337(75.6)$ & $1.112(70.2)$ & 1.00 & (Ref.) & 0.0021 \\
\hline Centre & $214(18.8)$ & $52(11.7)$ & $266(16.8)$ & 1.79 & $(1.29-2.49)$ & \\
\hline South & $149(13.1)$ & $57(12.8)$ & $206(13.0)$ & 1.14 & $(0.82-1.58)$ & \\
\hline Missing & 10 & 7 & 17 & & & \\
\hline \multicolumn{7}{|l|}{ Education } \\
\hline First level & $187(17.5)$ & $95(21.7)$ & $282(18.7)$ & 0.64 & $(0.48-0.87)$ & 0.0019 \\
\hline Second level & $352(33.0)$ & $170(38.8)$ & $522(34.7)$ & 0.68 & $(0.53-0.87)$ & \\
\hline Tertiary level & $528(49.5)$ & $173(39.5)$ & $701(46.6)$ & 1.00 & (Ref.) & \\
\hline Missing & 81 & 15 & 96 & & & \\
\hline \multicolumn{7}{|c|}{ Actually employed } \\
\hline Yes & $684(65.7)$ & $286(66.7)$ & $970(66.0)$ & 1.00 & (Ref.) & 0.7238 \\
\hline No & $357(34.3)$ & $143(33.3)$ & $500(34.0)$ & 1.04 & $(0.82-1.32)$ & \\
\hline Missing & 107 & 24 & 131 & & & \\
\hline \multicolumn{7}{|l|}{ Work } \\
\hline Employers & $724(65.2)$ & $277(63.5)$ & $1.001(64.7)$ & 1.00 & (Ref.) & 0.5101 \\
\hline Freelance & $203(18.3)$ & 78 (17.9) & $281(18.2)$ & 1.00 & $(0.74-1.34)$ & \\
\hline Housewives & $128(11.5)$ & $62(14.2)$ & $190(12.3)$ & 0.79 & $(0.57-1.10)$ & \\
\hline Unemployed & $56(5.0)$ & $19(4.4)$ & $75(4.8)$ & & & \\
\hline Missing & 37 & 17 & 54 & & & \\
\hline \multicolumn{7}{|l|}{ Smart working } \\
\hline Yes & $408(61.5)$ & $181(64.9)$ & $589(62.5)$ & 1.00 & (Ref.) & 0.3342 \\
\hline No & $255(38.5)$ & $98(35.1)$ & $353(37.5)$ & 1.15 & $(0.86-1.54)$ & \\
\hline Missing & 21 & 7 & 28 & & & \\
\hline \multicolumn{7}{|c|}{ Difficulties balance work/child } \\
\hline Yes & $578(87.8)$ & 192 (69.6) & $770(82.4)$ & 3.16 & $(2.23-4.47)$ & $<0.0001$ \\
\hline No & $80(12.2)$ & $84(30.4)$ & $164(17.6)$ & 1.00 & (Ref.) & \\
\hline Missing & 26 & 10 & 36 & & & \\
\hline Children & 1148 & 453 & 1601 & & & \\
\hline Age & $8,0(7,0-9,0)$ & $12,0(11,0-13,0)$ & $9,0(7,0-11,0)$ & & & $<0.0001$ \\
\hline \multicolumn{7}{|l|}{ Gender } \\
\hline Female & $545(48.2)$ & $213(47.7)$ & $758(48.1)$ & 0.98 & $(0.78-1.22)$ & 0.8357 \\
\hline Male & $585(51.8)$ & $234(52.3)$ & 819 (51.9) & 1.00 & (Ref.) & \\
\hline Missing & 18 & 6 & 24 & & & \\
\hline \multicolumn{7}{|l|}{ Brothers/Sisters } \\
\hline Yes & $637(57.9)$ & 307 (70.1) & $944(61.4)$ & 1.00 & (Ref.) & $<0.0001$ \\
\hline No & $463(42.1)$ & 131 (29.9) & $594(38.6)$ & 1.70 & $(1.34-2.16)$ & \\
\hline Missing & 48 & 15 & 63 & & & \\
\hline \multicolumn{7}{|l|}{ Type of School } \\
\hline Public & $917(88.8)$ & $418(93.9)$ & $1.335(90.3)$ & 1.00 & (Ref.) & 0.0021 \\
\hline Private & $116(11.2)$ & $27(6.1)$ & $143(9.7)$ & 1.96 & $(1.27-3.02)$ & \\
\hline Missing & 115 & 8 & 123 & & & \\
\hline
\end{tabular}


Table 1 Socio-demographics mothers and children variables by School (Continued)

\begin{tabular}{|c|c|c|c|c|c|c|}
\hline & Primary school & Middle school & Total & OR & $\mathrm{Cl} 95 \%$ & $p$-value \\
\hline \multicolumn{7}{|c|}{ School performance } \\
\hline No sufficient & $11(1.0)$ & $8(1.8)$ & $19(1.2)$ & 0.48 & $(0.19-1.21)$ & $<0.0001$ \\
\hline Sufficient & $94(8.4)$ & $65(14.4)$ & $159(10.2)$ & 0.50 & $(0.34-0.73)$ & \\
\hline Good & $305(27.3)$ & $180(40.0)$ & $485(31.0)$ & 0.59 & $(0.45-0.77)$ & \\
\hline Very good & $378(33.9)$ & $131(29.1)$ & $509(32.5)$ & 1.00 & (Ref.) & \\
\hline Excellent & $328(29.4)$ & $66(14.7)$ & $394(25.2)$ & 1.72 & $(1.24-2.40)$ & \\
\hline Missing & 32 & 3 & 35 & & & \\
\hline Total & 1148 & 435 & 1601 & & & \\
\hline
\end{tabular}

1.50, CI 1.06 - 2.10) compared to middle school children (Table 3).

\section{Special needs students}

In all, $5.5 \%$ of our sample suffered from a chronic disorder, such as a medical (25.6\%) or physical condition (11.5\%) or neurodevelopmental disorder (66.7\%). Children with a support teacher (5.9\%) attended lessons online only once a week (53.7\%). Compensatory measures consisted mainly in concept maps (51\%), additional time (39\%), and reduced tasks (33.5\%). In all, $14.7 \%$ of the children did not receive any support. The main teaching mode was via video lessons (77.4\%), and no differences emerged between primary and middle school students.

\section{Mothers' difficulties and opinions on distance learning}

Compared to middle school, mothers of primary school students expressed worse opinions about distance learning. They reported greater effort $(\mathrm{OR}=3.15$, CI $2.50-$ $3.98)$ and higher need for commitment $(\mathrm{OR}=2.21, \mathrm{CI}$ $1.71-2.85)$ in supporting their children, and sometimes in replacing teachers (OR 3.86, CI 2.99- 4.97), for example when their child did not know how to solve a math problem. Half of the mothers were faced with difficulties in daily organisation and $82.3 \%$ reported not having enough time for their children and the whole family $(\mathrm{OR}=3.53$, CI 2.54-4.88). Primary school children were less independent $(\mathrm{OR}=4.14, \mathrm{CI} 3.26-5.27)$, with low levels of learning $(\mathrm{OR}=1.63, \mathrm{CI} 1.29-2.07)$. Mothers rejected distance learning for the future $(72.2 \%)$, in particular for primary school students $(\mathrm{OR}=1.95$, CI 1.542.48). Before COVID-19, $45 \%$ of mothers received help from grandparents in taking care of their children, while only $28.8 \%$ could rely on grandparents in the future, in particular for middle school children $(\mathrm{OR}=1.74, \mathrm{CI}$ 1.35-2.26) (Table 4).

\section{Discussion}

COVID-19 has forced the government to take drastic preventive actions, such as the quarantine and school closure. Low transmission of SARS-CoV-2 within schools, at least among younger students was reported. However, entire schools are frequently closed in the fear of larger outbreaks [32]. Our research explored the current educational situation in one of the most affected countries in the world and how distance learning had been organised in response to school closure. Home confinement was seen as a limitation of freedom for children, who were forced to drastically change their habits, while school closure deprived children of socialisation opportunities, with negative consequences on levels of autonomy and independence. Schools have always been at the heart of the rights of children and adolescents and their families [33]. School is, indeed, a place where children can pursue new interests, build relationships, confront themselves with peers, grow up and become adults. This survey highlighted negative effects of distance learning on children's attitude and behaviour and found that, in our sample, distance learning was not well regarded by parents because of the lack of organisation and planned routine, and because of the absence of assessment of the children's work and the difficulty in reaching the teachers. One of the most frightening data highlighted by our research is that $1.5 \%$ of our sample did not participate in distance learning because they did not have access to technological tools. This result is in line with a global analysis of the potential reach of remote learning policies conducted by UNICEF in 33 countries. Globally, at least 31 percent of students from pre-primary to upper secondary schools cannot be reached due to either a lack of policies supporting digital and broadcast remote learning or a lack of the household assets needed to receive digital or broadcast instruction [30].

Our results support previous research focused on the importance of school and social interactions for the well-being of children and their role in preventing the development of psychological distress [15] and other mental health conditions such as anxiety and depression $[17,31]$. The lack of structured, daily school life and the absence of interactions with peers, together with an instable quarantine routine, had an impact on the 
Table 2 Distance Learning organisation by School

\begin{tabular}{|c|c|c|c|c|c|c|}
\hline & Primary school & Middle school & Total & OR & $\mathrm{Cl} 95 \%$ & p-value \\
\hline \multicolumn{7}{|l|}{ Instruments (flag) } \\
\hline Computer & $130(11.5)$ & $70(15.6)$ & $200(12.6)$ & 0.70 & $(0.51-0.96)$ & 0.0275 \\
\hline PC & $727(64.2)$ & $320(71.1)$ & $1.047(66.1)$ & 0.73 & $(0.57-0.92)$ & 0.0084 \\
\hline Smartphone/Tablet & $666(58.8)$ & $277(61.6)$ & $943(59.6)$ & 0.89 & $(0.71-1.11)$ & 0.3105 \\
\hline Books & $800(70.6)$ & $280(62.2)$ & $1.080(68.2)$ & 1.46 & $(1.16-1.83)$ & 0.0012 \\
\hline Missing & 15 & 3 & 18 & & & \\
\hline \multicolumn{7}{|l|}{ Difficulties with technologies } \\
\hline Not used & $17(1.5)$ & $7(1.6)$ & $24(1.5)$ & 0.90 & $(0.37-2.18)$ & 0.0579 \\
\hline Some & $184(16.3)$ & $95(21.4)$ & $279(17.7)$ & 0.71 & $(0.54-0.94)$ & \\
\hline None & $927(82.2)$ & $342(77.0)$ & $1.269(80.7)$ & 1.00 & (Ref.) & \\
\hline Missing & 20 & 9 & 29 & & & \\
\hline \multicolumn{7}{|l|}{ Frequency of PC use } \\
\hline Low & $112(10.2)$ & $17(3.8)$ & $129(8.3)$ & 3.48 & $(2.06-5.90)$ & $<0.0001$ \\
\hline Moderate & $355(32.3)$ & $95(21.3)$ & $450(29.1)$ & 1.97 & $(1.52-2.57)$ & \\
\hline Often & $632(57.5)$ & $334(74.9)$ & $966(62.5)$ & 1.00 & (Ref.) & \\
\hline Missing & 12 & 3 & 15 & & & \\
\hline \multicolumn{7}{|l|}{ Type of tools (flag) } \\
\hline Edmodo, Google Suits for Education & $678(59.8)$ & $265(58.8)$ & $943(59.5)$ & 1.04 & $(0.84-1.30)$ & 0.7062 \\
\hline WhatsApp/FaceTime & $458(40.4)$ & $219(48.6)$ & $677(42.7)$ & 0.72 & $(0.58-0.89)$ & 0.0030 \\
\hline Zoom, Skype & $273(24.1)$ & $90(20.0)$ & $363(22.9)$ & 1.27 & $(0.97-1.66)$ & 0.0783 \\
\hline Electronic register & $628(55.4)$ & $331(73.4)$ & $959(60.5)$ & 0.45 & $(0.35-0.57)$ & $<0.0001$ \\
\hline YouTube & $427(37.7)$ & $133(29.5)$ & $560(35.3)$ & 1.44 & $(1.14-1.83)$ & 0.0022 \\
\hline None & $496(43.7)$ & $260(57.6)$ & $756(47.7)$ & 0.57 & $(0.46-0.71)$ & $<0.0001$ \\
\hline \multicolumn{7}{|l|}{ Missing } \\
\hline \multicolumn{7}{|l|}{ Frequency of web tools use } \\
\hline Low & $199(28.6)$ & $38(10.2)$ & $237(22.1)$ & 3.58 & $(2.45-5.23)$ & $<0.0001$ \\
\hline Moderate & $287(41.2)$ & $97(26.0)$ & $384(35.9)$ & 2.02 & $(1.53-2.67)$ & \\
\hline Often & $401(57.5)$ & $274(73.5)$ & $675(63.1)$ & 1.00 & (Ref.) & \\
\hline Missing & 9 & 2 & 11 & & & \\
\hline \multicolumn{7}{|l|}{ Teaching modalities (flag) } \\
\hline Homework & $1.044(91.0)$ & $416(92.4)$ & $1.460(91.4)$ & 0.83 & $(0.55-1.24)$ & 0.3605 \\
\hline Film/ Documentaries & $718(62.6)$ & $287(63.8)$ & $1.005(62.9)$ & 0.95 & $(0.76-1.19)$ & 0.6606 \\
\hline School Material & $686(59.8)$ & $263(58.4)$ & $949(59.4)$ & 1.06 & $(0.85-1.32)$ & 0.6176 \\
\hline Video-lessons & $936(81.6)$ & $414(92.0)$ & $1.350(84.5)$ & 0.39 & $(0.27-0.56)$ & $<0.0001$ \\
\hline Books & $663(57.8)$ & $327(72.7)$ & $990(62.0)$ & 0.52 & $(0.41-0.65)$ & $<0.0001$ \\
\hline Missing & 1 & 3 & 4 & & & \\
\hline \multicolumn{7}{|l|}{ Distance learning organisation } \\
\hline Yes & $766(71.3)$ & $335(77.9)$ & $1.101(73.2)$ & 1.00 & (Ref.) & 0.0092 \\
\hline No & $308(28.7)$ & $95(22.1)$ & $403(26.8)$ & 1.42 & $(1.09-1.85)$ & \\
\hline Missing & 74 & 23 & 97 & & & \\
\hline \multicolumn{7}{|l|}{ Stable routine } \\
\hline Yes & $271(24.7)$ & $149(34.2)$ & $420(27.4)$ & 1.00 & (Ref.) & 0.0002 \\
\hline No & $826(75.3)$ & 287 (65.8) & $1.113(72.6)$ & 1.50 & $(1.24-2.01)$ & \\
\hline Missing & 51 & 17 & 68 & & & \\
\hline
\end{tabular}


Table 2 Distance Learning organisation by School (Continued)

\begin{tabular}{|c|c|c|c|c|c|c|}
\hline & Primary school & Middle school & Total & OR & $\mathrm{Cl} 95 \%$ & $p$-value \\
\hline \multicolumn{7}{|l|}{ Child effort } \\
\hline Yes & $899(81.7)$ & $352(80.0)$ & $1.251(81.2)$ & 1.00 & (Ref.) & 0.4329 \\
\hline No & $201(18.3)$ & $88(20.0)$ & $289(18.8)$ & 0.89 & $(0.68-1.18)$ & \\
\hline Missing & 48 & 13 & 61 & & & \\
\hline \multicolumn{7}{|c|}{ Teachers reachability } \\
\hline Yes & $786(72.6)$ & $256(59.4)$ & $1.042(68.9)$ & 1.00 & (Ref.) & $<0.0001$ \\
\hline No & $296(27.4)$ & $175(40.6)$ & $471(31.1)$ & 0.55 & $(0.44-0.70)$ & \\
\hline Missing & 66 & 22 & 88 & & & \\
\hline \multicolumn{7}{|l|}{ Assessment } \\
\hline Yes & $993(88.5)$ & $432(95.6)$ & $1.425(90.5)$ & 1.00 & (Ref.) & $<0.0001$ \\
\hline No & $129(11.5)$ & $20(4.4)$ & $149(9.5)$ & 2.81 & $(1.73-4.55)$ & \\
\hline Missing & 26 & 1 & 27 & & & \\
\hline \multicolumn{7}{|c|}{ Homework revision } \\
\hline Teachers & $846(75.1)$ & $321(72.3)$ & $1.167(74.3)$ & 1.00 & (Ref.) & 0.0449 \\
\hline Self-revision & $65(5.8)$ & $17(3.8)$ & $82(5.2)$ & 1.45 & $(0.84-2.51)$ & \\
\hline Both & $215(19.1)$ & $106(23.9)$ & $321(20.4)$ & 0.77 & $(0.59-1.00)$ & \\
\hline Missing & 22 & 9 & 31 & & & \\
\hline \multicolumn{7}{|c|}{ Grades attribution } \\
\hline Yes & $517(46.9)$ & $343(80.0)$ & $860(56.2)$ & 1.00 & (Ref.) & $<0.0001$ \\
\hline No & $585(53.1)$ & $86(20.0)$ & $671(43.8)$ & 4.51 & $(3.46-5.88)$ & \\
\hline Missing & 46 & 24 & 70 & & & \\
\hline \multicolumn{7}{|c|}{ Planned assessment } \\
\hline Yes & $558(59.3)$ & $327(77.7)$ & $885(65.0)$ & 1.00 & (Ref.) & $<0.0001$ \\
\hline No & $383(40.7)$ & $94(22.3)$ & $477(35.0)$ & 2.39 & $(1.83-3.11)$ & \\
\hline Missing & 52 & 11 & 63 & & & \\
\hline \multicolumn{7}{|c|}{ Grades variability } \\
\hline Higher & $62(12.5)$ & $53(16.2)$ & $115(14.0)$ & 0.68 & $(0.46-1.02)$ & 0.0037 \\
\hline Same & $398(80.4)$ & $232(70.9)$ & $630(76.6)$ & 1.00 & (Ref.) & \\
\hline Lower & $35(7.1)$ & $42(12.8)$ & $77(9.4)$ & 0.49 & $(0.30-0.78)$ & \\
\hline Missing & 22 & 16 & 38 & & & \\
\hline
\end{tabular}

emotional and behavioural conditions of children. In other surveys mothers reported behavioural changes in their children during lockdown, such as an increment in restlessness and aggressiveness, boredom, sadness, attention deficit, hyperactivity, and regressive behaviours [32, 33]. Mothers also reported difficulties in motivating their child to study [24].

These behavioural and emotional impairments were greater in primary school students than in middle school students: the instable and badly structured distance learning for the youngest led to increased levels of restlessness and aggressiveness, little commitment during lessons, and scarce autonomy. In this unusual situation, parents were asked to support their children, in particular the youngest, in the educational process and, at the same time, to work and provide home care, with negative consequences on their own distress level [24]. Some mothers reported not having enough time to help their child with schoolwork, while grandparents and family friends were not able to help due to the lockdown [22]. According to the literature [9, 33, 34], families with two or more children and living in low socio-economic conditions were penalised because of lack of space, time dedicated to children, and difficulties with technologies [35-38]. Quarantine has increased the gap between families with high and low socio-economic levels, increased differences, and destroyed the concept of equal opportunity. This situation not only produced social inequalities, but also educational inequalities, and did so to an even greater extent in those suffering from a chronic disorder or a disability. These children did not 
Table 3 Children attitude and behaviour by School

\begin{tabular}{ll}
\hline & Primary school \\
\hline $\begin{array}{l}\text { Attention span } \\
\leq 20 \text { min }\end{array}$ & $317(28.3)$ \\
20 min- $1 \mathrm{~h}$ & $673(60.1)$ \\
$>1 \mathrm{~h}$ & $129(11.5)$ \\
Missing & 29 \\
Breaks frequency & \\
Every 10 min & $239(21.6)$ \\
Every 20-30 min & $523(47.2)$ \\
Every 1 h & $345(31.2)$ \\
Missing & 41
\end{tabular}

Restlessness during distance learning

$\begin{array}{ll}\text { Yes } & 534(48.3) \\ \text { No } & 572(51.7)\end{array}$

Missing

$$
42
$$

Distance learning duration

$\begin{array}{rl}\leq 2 \mathrm{~h} & 737(65.5) \\ 2-4 \mathrm{~h} & 340(30.2) \\ 4-6 \mathrm{~h} & 48(4.3) \\ \text { Missing } & 23\end{array}$

Screen time other than distance learning

$\begin{array}{rll}\leq 2 h & 660(66.8) & 133(33.8) \\ 2-4 h & 302(30.6) & 201(51.1) \\ 4-6 h & 26(2.6) & 59(15.0) \\ \text { Missing } & 160 & 60\end{array}$

89 (19.8)

267 (59.5)

93 (20.7)

4

$60(13.6)$
$304(68.9)$
$77(17.5)$
12

$37(8.4)$

182 (41.6)

$219(50.0)$

15

$179(40.5)$

$263(59.5)$

11

$713(46.1)$

835 (53.9)

1.37

(1.10-1.72)

(Ref.)

53

$826(52.5)$
$607(38.6)$
$141(9.0)$
27

793 (57.4)

503 (36.4)

$85(6.2)$

1.00

0.30

0.09

(Ref.)

(0.12-0.20)

(0.04-0.09)

Internet activities (flag)

$\begin{array}{ll}\text { Videogames } & 463(43.2) \\ \text { Tutorial } & 387(36.1) \\ \text { Film/ TV series } & 778(72.6) \\ \text { Social } & 122(11.4) \\ \text { Study } & 310(28.9) \\ \text { Missing } & 77\end{array}$

\section{Behaviour changes}

$$
\begin{aligned}
& \text { Yes } \\
& \text { No }
\end{aligned}
$$

Missing

$$
692(62.5)
$$$$
416 \text { (37.5) }
$$

40

$$
\begin{aligned}
& 264(59.1) \\
& 197(44.1) \\
& 303(67.8) \\
& 201(45.0) \\
& 174(38.9) \\
& 6
\end{aligned}
$$

220

$727(47.9)$
$584(38.5)$
$1.081(71.2)$
$323(21.3)$
$484(31.9)$
83

$<0.0001$

$$
\text { (0.57-0.90) }
$$

0.0038

$1.26(0.99-1.60)$

0.0568

0.16

(0.12-0.21)

$<0.0001$

0.64

(0.51-0.81)

0.0001

241 (54.5)

201 (45.5)

11

$933(60.2)$
$617(39.8)$
51

1.39

1.00

(1.11-1.73)

(Ref.)

\section{Symptoms (flag)}

$\begin{array}{ll}\text { Restlessness } & 459(69.1) \\ \text { Aggressiveness } & 221(33.3) \\ \text { Anxiety } & 176(26.5) \\ \text { Sleeping rhythm } & 270(40.7) \\ \text { Mood lability } & 107(16.1) \\ \text { Missing } & 28\end{array}$

\section{Restlessness}

0.0006

57 (25.0)

1.50

(1.06-2.10)

0.0198

78 (34.2)

254 (28.5)

(0.50-0.96)

0.0261

96 (42.1)

366 (41.0)

0.94

(0.69-1.28)

0.7024

43 (18.9)

13

150 (16.8)

0.83

(0.56-1.22)

0.3390 
Table 3 Children attitude and behaviour by School (Continued)

\begin{tabular}{|c|c|c|c|c|c|c|}
\hline & Primary school & Middle school & Total & OR & $\mathrm{Cl} 95 \%$ & p-value \\
\hline Mild & $103(9.4)$ & $45(10.2)$ & $148(9.6)$ & 1.10 & $(0.76-1.61)$ & \\
\hline Moderate & $274(25.0)$ & $72(16.3)$ & $346(22.5)$ & 1.84 & $(1.37-2.46)$ & \\
\hline Severe & $68(6.2)$ & $11(2.5)$ & $79(5.1)$ & 1.50 & $(1.06-2.10)$ & \\
\hline Missing & 54 & 12 & 66 & & & \\
\hline \multicolumn{7}{|c|}{ Aggressiveness } \\
\hline No & $887(81.8)$ & $385(87.7)$ & $1.272(83.5)$ & 1.00 & (Ref) & 0.0419 \\
\hline Mild & $41(3.8)$ & $9(2.1)$ & $50(3.3)$ & 1.98 & $(0.95-4.1)$ & \\
\hline Moderate & $117(10.8)$ & $34(7.7)$ & $151(9.9)$ & 1.49 & $(1.00-2.23)$ & \\
\hline Severe & $39(3.6)$ & $11(2.5)$ & $50(3.3)$ & 1.54 & $(0.78-3.04)$ & \\
\hline Missing & 64 & 14 & 78 & & & \\
\hline \multicolumn{7}{|l|}{ Anxiety } \\
\hline No & $932(84.3)$ & $364(82.4)$ & $1.296(83.7)$ & 1.00 & (Ref) & 0.4920 \\
\hline Mild & $52(4.7)$ & $24(5.4)$ & $76(4.9)$ & 0.85 & $(0.51-1.39)$ & \\
\hline Moderate & $89(8.0)$ & $44(10.0)$ & $133(8.6)$ & 0.79 & $(0.54-1.16)$ & \\
\hline Severe & $33(3.0)$ & $10(2.3)$ & $43(2.8)$ & 1.29 & $(0.63-2.64)$ & \\
\hline Missing & 42 & 11 & 53 & & & \\
\hline \multicolumn{7}{|c|}{ Sleeping rhythm } \\
\hline No & $838(76.3)$ & $346(79.0)$ & $1184(77.1)$ & 1.00 & (Ref) & 0.1512 \\
\hline Mild & $62(5.6)$ & $13(3.0)$ & $75(4.9)$ & 1.97 & $(1.07-3.63)$ & \\
\hline Moderate & $112(10.2)$ & $48(11.0)$ & $160(10.4)$ & 0.96 & $(0.67-1.38)$ & \\
\hline Severe & $86(7.8)$ & $31(7.1)$ & $117(7.6)$ & 1.15 & $(0.75-1.76)$ & \\
\hline Missing & 50 & 15 & 65 & & & \\
\hline \multicolumn{7}{|c|}{ Mood lability } \\
\hline No & 1001 (91.0) & $399(90.5)$ & $1.400(90.9)$ & 1.00 & (Ref) & 0.3359 \\
\hline Mild & $38(3.5)$ & $10(2.3)$ & $48(3.1)$ & 1.51 & $(0.75-3.07)$ & \\
\hline Moderate & $42(3.8)$ & $24(5.4)$ & $66(4.3)$ & 0.70 & $(0.42-1.17)$ & \\
\hline Severe & $19(1.7)$ & $8(1.8)$ & $27(1.8)$ & 0.95 & $(0.41-2.18)$ & \\
\hline Missing & 48 & 12 & 60 & & & \\
\hline
\end{tabular}

receive adequate support [11]. Moreover, distance learning deleted social interaction and neglected their special needs.

\section{Strengths and limitations}

There are strengths and limitations to our study. The web data collection has considerable potential, even if the large sample of participants is not representative of the population of Italian mothers. Most participants (50.7\%) were mothers from the Lombardy Region, employed, with two or more sons. Characteristics of responders may be correlated with their perceived difficulty as well as their decision to participate in the study. Moreover, childrens' attitudes and behavioural changes have been described from maternal perspective only: this could be considered a potential bias because, as mentioned above, mothers were the ones most overwhelmed by this pandemic situation.
In the future it could be useful to examine effects on children from both parents' perspectives and to analyse their potential correlation. High-functioning users of social media who are already engaged in similar initiatives might be over-represented. On the other hand, families without technological tools or internet connection may be faced with the impossibility to participate in the study. Another limitation is the lack of inclusion of minorities and more fragile populations on several point of views, including on an economic and social point of view. Lastly, the use of cross-sectional self-reported data, as in the present study, precludes attribution of causality. The findings reflect important associations among the variables we studied, and strong corroboration between these findings and existing literature about children's educational needs, suggesting the need for future longitudinal studies in this area. 
Table 4 Mothers' opinion about Distance learning by School

\begin{tabular}{|c|c|c|c|c|c|c|}
\hline & Primary school & Middle school & Total & OR & $\mathrm{Cl} 95 \%$ & $p$-value \\
\hline \multicolumn{7}{|l|}{ Mother effort } \\
\hline Yes & $798(73.5)$ & $199(46.8)$ & $997(66.0)$ & 3.15 & $(2.50-3.98)$ & $<0.0001$ \\
\hline No & $287(26.5)$ & $226(53.2)$ & $513(34.0)$ & 1.00 & (Ref.) & \\
\hline Missing & 63 & 28 & 91 & & & \\
\hline \multicolumn{7}{|c|}{ Mother commitment } \\
\hline Yes & $896(82.5)$ & $300(68.0)$ & $1.196(78.3)$ & 2.21 & $(1.71-2.85)$ & \\
\hline No & $190(17.5)$ & $141(32.0)$ & $331(21.7)$ & 1.00 & (Ref.) & $<0.0001$ \\
\hline Missing & 62 & 12 & 74 & & & \\
\hline \multicolumn{7}{|c|}{ Replacing teachers } \\
\hline Yes & $936(85.0)$ & $260(59.5)$ & $1.196(77.8)$ & 3.86 & $(2.99-4.97)$ & \\
\hline No & $165(15.0)$ & $177(40.5)$ & $342(22.2)$ & 1.00 & (Ref.) & $<0.0001$ \\
\hline Missing & 47 & 16 & 63 & & & \\
\hline \multicolumn{7}{|c|}{ Difficulties with (flag) } \\
\hline Organisation & $541(49.7)$ & $212(51.0)$ & $753(50.1)$ & 0.87 & $(0.64-1.17)$ & 0.3526 \\
\hline Time dedicated & $895(82.3)$ & $223(53.6)$ & $1.118(74.3)$ & 3.53 & $(2.54-4.88)$ & $<0.0001$ \\
\hline Technologies & $523(48.1)$ & $266(63.9)$ & $789(52.5)$ & 0.52 & $(0.38-0.71)$ & $<0.0001$ \\
\hline Missing & 60 & 37 & 97 & & & \\
\hline \multicolumn{7}{|l|}{ Child autonomy } \\
\hline Yes & $205(18.1)$ & $214(47.9)$ & $419(26.6)$ & 1.00 & (Ref.) & $<0.0001$ \\
\hline No & $925(81.9)$ & $233(52.1)$ & $1.158(73.4)$ & 4.14 & $(3.26-5.269$ & \\
\hline Missing & 18 & 6 & 24 & & & \\
\hline \multicolumn{7}{|c|}{ Child commitment } \\
\hline Yes & $458(41.1)$ & $276(63.3)$ & $734(47.3)$ & 1.00 & (Ref.) & $<0.0001$ \\
\hline No & $657(58.9)$ & $160(36.7)$ & $817(52.7)$ & 0.40 & $(0.32-0.51)$ & \\
\hline Missing & 33 & 17 & 50 & & & \\
\hline \multicolumn{7}{|l|}{ Scarce learning } \\
\hline Yes & $455(40.6)$ & $130(29.5)$ & $585(37.4)$ & 1.63 & $(1.29-2.07)$ & $<0.0001$ \\
\hline No & $667(59.4)$ & $311(70.5)$ & $978(62.6)$ & 1.00 & (Ref.) & \\
\hline Missing & 26 & 12 & 38 & & & \\
\hline \multicolumn{7}{|c|}{ Distance learning in the future } \\
\hline Yes & $262(23.8)$ & $165(37.9)$ & $427(27.8)$ & 1.00 & (Ref.) & $<0.0001$ \\
\hline No & $838(76.2)$ & $270(62.1)$ & $1.108(72.2)$ & 1.95 & $(1.54-2.48)$ & \\
\hline Missing & 48 & 18 & 66 & & & \\
\hline \multicolumn{7}{|c|}{ Child care pre COVID-19 (flag) } \\
\hline Parents & $821(72.5)$ & $333(74.7)$ & $1.154(73.1)$ & 0.90 & $(0.70-1.15)$ & 0.3885 \\
\hline Grandparents & $541(47.8)$ & $178(39.9)$ & $719(45.6)$ & 1.38 & $(1.10-1.72)$ & 0.0046 \\
\hline Others & $230(20.3)$ & $74(16.6)$ & $304(19.3)$ & 1.28 & $(0.96-1.71)$ & 0.0910 \\
\hline Missing & 16 & 7 & 23 & & & \\
\hline \multicolumn{7}{|c|}{ Child care post COVID-19 (flag) } \\
\hline Parents & $963(84.9)$ & $391(87.9)$ & $1.354(85.8)$ & 0.78 & $(0.56-1.08)$ & 0.1321 \\
\hline Grandparents & $361(31.8)$ & $94(21.1)$ & $455(28.8)$ & 1.74 & $(1.35-2.26)$ & $<0.0001$ \\
\hline Others & $164(14.5)$ & $53(11.9)$ & $217(13.7)$ & 1.25 & $(0.90-1.74)$ & 0.1852 \\
\hline Missing & 14 & 8 & 22 & & & \\
\hline
\end{tabular}




\section{Conclusions}

Despite the efforts provided by teachers, distance learning turned out to be useless and ineffective in replacing physical presence in school; low levels of learning, insufficient cognitive stimulation, and absence of social interactions created a gap that will be hard to fill, especially for young children, who have lost almost one year of school. One year of failure to learn may have severe repercussions on students' cognitive, emotional, and relational capacities. If students do not have adequate home access to an internet device that is appropriate for learning activities, or if online learning is otherwise ineffective for them, their academic progress may be at risk. Although the extent to which students will be affected is unknown at this time, a Statistics Canada study found that students who received less instructional time because they were born just after the school entry cut-off date performed more poorly in standardized tests in reading, mathematics, and science [35, 39].

The current study is important because it highlighted the importance of school for the future of our children and its capacity to guarantee children's educational rights and psychological well-being. The results of this research could be considered as a starting point for thinking about more supportive modalities for school and family, so that both will continue to be a point of reference for children. Investments in education are needed in order to provide a better school system, because school is more than just learning, school is a right.

\section{Supplementary Information}

The online version contains supplementary material available at https:/doi. org/10.1186/s12889-021-11026-x.

Additional file 1. Questionnaire used for the survey.

\section{Acknowledgments}

The co-operation of the participating students and their families is gratefully acknowledged. The authors would like to acknowledge Chiara Pandolfini for language editing and Daniela Miglio for editing.

\section{Authors' contributions}

$F S . M B, G S$ and $A C$ designed the study and the questions of the survey; MC, $\mathrm{MZ}$ and RC conducted the data analysis; FS and MB interpreted the data and drafted the article. All authors critically revised the article and reviewed the final draft of the article. MB is the guarantor. The author(s) read and approved the final manuscript.

\section{Funding}

The study had no sponsor so expenses incurred for study design, data collection, data analysis, data interpretation, and writing of the report were paid for with department funds. The corresponding author had full access to all the data in the study and had final responsibility for the decision to submit for publication.

\section{Availability of data and materials}

The datasets used and/or analysed during the current study are available from the corresponding author on reasonable request.

\section{Declarations}

\section{Ethics approval and consent to participate}

The authors assert that all procedures contributing to this work comply with the ethical standards of the relevant national and institutional guidelines on care and clinical research. This study has been conducted in accordance with the Helsinky Declaration. The study was approved by the ethics committee of the San Paolo hospital of Milan, Italy (2020/ST/106).

Participation was addressed only to parents, minors were not involved, and it was voluntary and free; no incentives were offered to complete it. Informed consent to participate in the study was obtained before accepting to take the survey. Once the link of the survey was clicked on, the participants were automatically directed to a section dedicated to the information on the study, followed by the written informed consent; if they were agree, they could click on "I'M AGREE", otherwise the survey ended automatically.

\section{Consent for publication}

Not applicable

\section{Competing interests}

All authors declare that they have no conflicts of interest.

Received: 16 October 2020 Accepted: 11 May 2021

Published online: 02 June 2021

References

1. The Ministry of Education, University and Research (MIUR). https://dati. istruzione.it/opendata/esploraidati. Accessed 30 Jul 2020.

2. United Nations Educational, Scientific, Cultural Organization (UNESCO) COVID-19 Educational Disruption and Response. https://en.unesco.org/ covid19/educationresponse. Accessed 30 Jul 2020

3. Cauchemez S, Ferguson NM, Wachtel C, Tegnell A, Saour G, Duncan B, et al. Closure of schools during an influenza pandemic. Lancet Infect Dis. 2009; 9(8):473-81. https://doi.org/10.1016/S1473-3099(09)70176-8.

4. Viner RM, Russell SJ, Croker H, Packer J, Ward J, Stansfield C, et al. School closure and management practices during coronavirus outbreaks including COVID-19: a rapid systematic review. Lancet Child Adolesc Health. 2020;4(5): 397-404. https://doi.org/10.1016/S2352-4642(20)30095-X

5. Ferguson NM, Laydon D, Nedjati-Gilani G, et al. Report 9: Impact of nonpharmaceutical interventions (NPIs) to reduce COVID-19 mortality and healthcare demand. Imperial College COVID-19 Response Team. https:// www.imperial.ac.uk/mrc-global-infectious-disease-analysis/covid-19/report-9impact-of-npis-on-covid-19. Accessed 29 Jul 2020.

6. Ludvigsson JF. Children are unlikely to be the main drivers of the COVID-19 pandemic - a systematic review. Acta Paediatr. 2020;109(8):1525-30. https:// doi.org/10.1111/apa.15371

7. Parri N, Magistà AM, Marchetti F, et al. Characteristic of COVID-19 infection in pediatric patients: early findings from two Italian pediatric research networks. Eur J Pediatr. 2020;179(8):1315-23. https://doi.org/10.1007/s00431020-03683-8.

8. National Institute of Statistics (ISTAT). https://www.istat.it/it/popolazione-e-fa miglie?dati. Accessed 30 Jul 2020

9. Van Lancker W, Parolin Z. COVID-19, school closures, and child poverty: a social crisis in the making lancet. Public Health. 2020;5(5):e243-4. https://doi. org/10.1016/S2468-2667(20)30084-0.

10. Andrew A, Cattan S, Costa-Dias M, et al. Learning during the lockdown: realtime data on children's experiences during home learning. Institute for Fiscal Studies Economic and Social Research Council. Nuffield Foundation, corp creators. (2020). https://www.ifs.org.uk/publications/14848. Accessed 29 Jul 2020

11. Zhang $H$, Nurius $P$, Sefidgar $Y$, et al. How Does COVID-19 impact Students with Disabilities/Health Concerns? arXiv. 2005:05438 https://arxiv.org/abs/2 005.05438. Accessed 29 Jul 2020.

12. Tawnell DH. U.S. News: Online Work Won't Be Graded or Counted at Many Schools. Wall Street Journal, Eastern edition; New York, N.Y. [New York, N.Y] 20 Mar 2020: A.3.

13. Asbury K, Fox L, Deniz E, Code A, Toseeb U. How is COVID-19 affecting the mental health of children with Special Educational Needs and Disabilities and their families? https://doi.org/10.31234/osf.io/sevyd. Accessed 29 Jul 2020 
14. Drane C, Vernon L, O'Shea S. The impact of "learning at home" on the educational outcomes of vulnerable children in Australia during the covid19 pandemic. Literature Review prepared by the National Centre for Student Equity in Higher Education, Australia, Curtin University, 2020. https://www.ncsehe.edu.au/wp-content/uploads/2020/04/NCSEHE_V2_Fina I_literaturereview-learningathome-covid19-final_30042020.pdf. Accessed 29 Jul 2020.

15. Brooks SK, Webster RK, Smith LE, Woodland L, Wessely S, Greenberg N, et al. The psychological impact of quarantine and how to reduce it: rapid review of the evidence. Lancet. 2020;395(10227):912-20. https://doi.org/10.1016/ S0140-6736(20)30460-8.

16. Fegert JM, Vitiello B, Plener PL, Clemens V. Challenges and burden of the coronavirus 2019 (COVID-19) pandemic for child and adolescent mental health: a narrative review to highlight clinical and research needs in the acute phase and the long return to normality. Child Adolesc Psychiatry Ment Health. 2020;14(1):20. https://doi.org/10.1186/s13034-020-00329-3.

17. Hankin BL. Depression from childhood through adolescence: risk mechanisms across multiple systems and levels of analysis. Curr Opin Psychol. 2015:4:13-20. https://doi.org/10.1016/j.copsyc.2015.01.003.

18. Urbina-Garcia A. Young Children's Mental Health: Impact of Social Isolation During The COVID-19 Lockdown and Effective Strategies; 2020. https://doi. org/10.31234/osf.io/g549x.

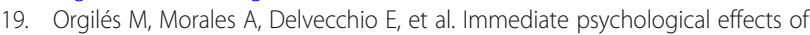
the COVID-19 quarantine in youth from Italy and Spain. Front Psychol. 2020 https://doi.org/10.31234/osf.io/5bpfz.

20. Brazendale K, Beets MW, Weaver RG, Chandler JL, Randel AB, TurnerMcGrievy GM, et al. Children's moderate to vigorous physical activity attending summer day camps. Am J Prev Med. 2017;53(1):78-84. https://doi. org/10.1016/j.amepre.2017.01.019.

21. Burgess S, Sievertsen HH. Schools, skills, and learning: The impact of COVID19 on education. VoxEu. org, 1. https://voxeu.org/article/impact-covid-19education. Accessed 29 Jul 2020.

22. Brom C, Lukavský J, Greger D, Hannemann T, Straková J, Švaříček R. Mandatory home education during the COVID-19 lockdown in the Czech Republic: a rapid survey of 1st-9th Graders' parents. Front Educ. 2020;5:103. https://doi.org/10.3389/feduc.2020.00103.

23. Spinelli M, Lionetti F, Pastore M, Fasolo M. Parents' stress and Children's psychological problems in families facing the COVID-19 outbreak in Italy. Front Psychol. 2020;11:1713. https://doi.org/10.3389/fpsyg.2020.01713.

24. Poll H. Stress in America ${ }^{\text {TM }}$ 2020. Stress in the time of COVID-19. Volume One. American Psychological Association. https://www.apa.org/news/press/ releases/stress/2020/stress-in-america-covid.pdf. Accessed 29 Jul 2020.

25. Nenko Y, Kybalna N, Snisarenko Y. The COVID-19 distance learning: insight from Ukrainian students. Revista Brasileira de Educação do Campo. 2020;5: $1-19$.

26. Foti $P$. Research in distance learning in greek kindergarten schools during the pandemic of covid-19: possibilities, dilemmas, limitations. Eur J Open Educ E-learn Stud. 2020;5:19-40.

27. Collins C, Ruppanner L, Christin Landivar L, Scarborough WJ. THE GENDER ED CONSEQUENCES OF A WEAK INFRASTRUCTURE OF CARE: school reopening plans and parents' employment during the COVID-19 pandemic. Gender Soc. 2021;35(2):180-93. https://doi.org/10.1177/08912432211001300.

28. Grasso M, Klicperová-Baker M, Koos S, Kosyakova Y, Petrillo A, Vlase I. The impact of the coronavirus crisis on European societies. What have we learnt and where do we go from here? - Introduction to the COVID volume. Eur Soc. 2021;23:S2-S32

29. Takaku R, Yokoyama I. What the COVID-19 school closure left in its wake: evidence from a regression discontinuity analysis in Japan. J Public Econ. 2021;195:104364. https://doi.org/10.1016/j.jpubeco.2020.104364.

30. Tiwari GK, Singh AK, Parihar P, Pandey R, Sharma DN, Rai PK. Understanding the perceived psychological distress and health outcomes of children during COVID-19 pandemic. Educ Develop Psychol. 2021:1-12. https://doi. org/10.1080/20590776.2021.1899749.

31. Blasius J, Brandt M. Representativeness in online surveys through stratified samples. Bull Soc Methodol. 2010;107(1):5-21. https://doi.org/10.1177/07591 06310369964.

32. Buonsenso D, De Rose C, Moroni R, Valentini P. SARS-CoV-2 infections in Italian schools: preliminary findings after 1 month of school opening during the second wave of the pandemic. Front Pediatr. 2021:8:615894. https://doi. org/10.3389/fped.2020.615894.
33. Buonsenso D, Roland D, De Rose C, et al. Schools closures during the COVID-19 pandemic: a catastrophic global situation. Pediatr Infect Dis J. 2021;40(4):e146-50. https://doi.org/10.1097/INF.0000000000003052.

34. United Nations Children's Fund. Covid-19: are children able to continue learning during school closures? A global analysis of the potential reach of remote learning policies using data from 100 countries. New York: UNICEF; 2020.

35. Allen KB, Benningfield M, Blackford JU. Childhood anxiety-if we know so much, why are we doing so little? JAMA Psychiatry. 2020;77(9):887-8. https://doi.org/10.1001/jamapsychiatry.2020.0585.

36. Orgilés M, Morales A, Delvecchio E, Mazzeschi C, Espada JP. Immediate psychological effects of the COVID-19 quarantine in youth from Italy and Spain. Front Psychol. 2020 Nov 6;11:579038. https://doi.org/10.3389/fpsyg.2 020.579038

37. Mantovani S, Picca M, Ferri P, Bove C, Manzoni P. Bambini e lockdown. La parola ai genitori. Università degli Studi di Milano Bicocca; 2020.

38. Bol T. Inequality in homeschooling during the Corona crisis in the Netherlands. First results from the LISS Panel; 2020. https://doi.org/10.31235/ osf.io/hf32q.

39. Frenette $M$. The returns to schooling on academic performance: evidence from large samples around school entry cut-off dates. Ottawa; 2008.

\section{Publisher's Note}

Springer Nature remains neutral with regard to jurisdictional claims in published maps and institutional affiliations.
Ready to submit your research? Choose BMC and benefit from:

- fast, convenient online submission

- thorough peer review by experienced researchers in your field

- rapid publication on acceptance

- support for research data, including large and complex data types

- gold Open Access which fosters wider collaboration and increased citations

- maximum visibility for your research: over $100 \mathrm{M}$ website views per year

At BMC, research is always in progress.

Learn more biomedcentral.com/submissions 